\title{
Flood risk modelling with LiDAR technology
}

\author{
A. Sole ${ }^{1}$, L. Giosa ${ }^{1}$, L. Nolè ${ }^{1}$, V. Medina ${ }^{2} \&$ A. Bateman ${ }^{2}$ \\ ${ }^{I}$ D.I.F.A. Università degli Studi della Basilicata, Italy \\ ${ }^{2}$ E.H.M.A. Universitat Politecnica de Catalunya, Spain
}

\begin{abstract}
Floods are one of the most serious, common and costly natural disasters that many countries are facing. Climate change and growing urban areas have dramatically increased the frequency and the severity of flood events. This has enhanced the interest of the Scientific Community and of public institutions into creating more accurate studies regarding the delineation of possible flood areas. In mountain and hill areas, it is much easier to mark the flood areas even with a one-dimensional scheme, while in lowlands the accurate delimitation of flood areas becomes much more difficult requiring a more detailed description of the territory. In particular, the definition of flood areas in coastal zones is extremely difficult because of the small changes in the land surface elevation and because of the presence of manmade structures that may significantly modify flood distribution. The area of study is the Ionian coastal plain of the Basilicata region (Southern Italy) crossed by five of the six main rivers of the region (Bradano, Basento, Cavone, Agri and Sinni). This work aims to: analyze the capacity of LaserScan data for the description of coastal morphology and to model flood risk areas; define a DTM able to describe the channel and floodplain morphology working on high resolution laser altimetry data and topographic data; define the most effective strategy for the delineation of flood areas using the comparison of the one dimensional model (Hec-Ras developed by the Hydrologic Engineering Center of USACE) versus the two dimensional scheme (MIKE $21 \mathrm{HD}$ by the Danish Hydraulic Institute, FLO-2D by O'Brien (FLO-2D User Manual. Version 2007.06), FLATModel by Medina et al. (Application of FLATModel, a $2 D$ finite volume code, to debris flows in the northeastern part of Iberian Peninsula, Landslides, Springer Verlag Editor, 2007)).

Keywords: topographic LiDAR data, hydrodynamic modeling, high resolution DEM.
\end{abstract}




\section{Introduction}

The evaluation of flood risk is very complex due to uncertainties of the problem and the oversight of observed data, especially for high return period discharges. This problem it is more difficult to solve in very flat areas because of the small changes in the land surface elevation models and, of the presence of manmade structures that may significantly modify flood distribution and variable flow resistance characteristics. Nowadays, the advent of computing resources allows us to easily apply two-dimensional model approaches, to study flood propagation in the areas in which it isn't correct to apply one-dimensional scheme to the flow. This is the case of coastal plains and lowlands. Two dimensional models are commonly used to evaluate flows in lowland catchments [3-5]. The topographic data resolution affects flow routing [6-8]. Generally good digital terrain models (DEMs) must contain an accurate description of micro topography (e.g. levees, embankments, roads, buildings) to create a computational mesh in which all the elements that support or keep flow dynamics and flood propagation are included. However, mesh sizes are typically limited by the computational resources available. A good river and floodplain description is possible using high resolution input data. Advances in models and in remote sensing techniques, make possible to generate high resolution DEMs, for whole watersheds at reasonable costs. The latest development in airborne laser scanning, makes it easy to produce high quality DEMs with accuracies less than $\pm 25 \mathrm{~cm}$, depending on the land cover, slope, flight parameters and environmental conditions.

\section{Case study}

The area of study is the Ionian coastal plain of Basilicata (Southern Italy) crossed by five of the main rivers of the region (Bradano, Basento, Cavone, Agri and Sinni). In this study, however, only the results of the Basento river are shown and an area of $40 \mathrm{~km}^{2}$ near the outlet of the Basento has been considered (fig. 1). Here the meandering river bed is about $8 \mathrm{~km}$ long and the river bed is

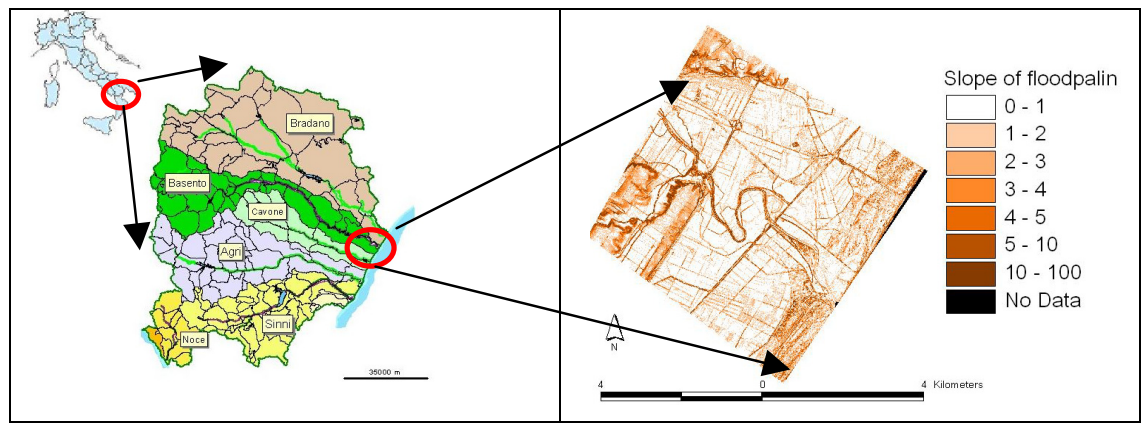

Figure 1: $\quad$ Location of the area of study and slope (\%) of the floodplain. 
characterized by mud and sand; the river bed slope is $0.03 \%$, cross sections have a top width of about $20 \mathrm{~m}$ and a depth of $4 \div 5 \mathrm{~m}$, typical data of this river morphology [9].

\section{Laser scanning system}

The digital terrain model forms the basis of the one and two dimensional hydraulic river flood models used.

The laser scanning technique quickly produces a DSM (Digital Surface Model): using specific software and different algorithms, a good quality DTM (Digital Terrain Model) can be obtained from the DSM [10]. The Airborne Laser scanner System $(A L S)$ is a system fastened on an aircraft, where the laser is used to measure the distance between the platform carrying the system and the surface of the ground. The Laser Scanning is an active remote sensing sensor because the system itself is the source of energy and does not depend on an external source. It is an integrated multi-sensor system, and consists of a Laser scanner, a GPS (Global Position System), an INS (Inertial Navigation System), a video camera and a computer. There are two steps in the measurement procedure of the airborne laser system: determining the position and rotation of the laser scanner and locating a ground object using the laser's measurements. During the first phase, the GPS and INS are integrated and calculate three positional and three rotational parameters of the laser system. During the second phase, the threedimensional coordinates of a ground object are determined using two optical pulses, the emitted and the received ones, and measuring the time difference between the emitted and the received pulses by the sensor. Finally the threedimensional coordinates are transferred onto the global coordinate system. There are many commercial companies who manufacture airborne laser survey systems. Data acquisition from the Ionian coast is formulated by a Topeye system called "Topeye MKII", located on an aircraft. This system works in Full waveform in order to give a better description of all ground elements. In fact, the "Topeye MKII" is able to record multiple echoes, not only the first and the last pulse $[10,11]$. The characteristics of the system are reported in Table 1.

Table 1: $\quad$ Sensor characteristics of Topoeye MKII.

\begin{tabular}{|l|c|}
\hline \multicolumn{2}{|c|}{ Laser Topeye MKII } \\
\hline Laser type & Fiber Laser with 2 channel \\
\hline Scanner type & Palmer Scanner \\
\hline Scan frequency & $50 \mathrm{kHz}$ \\
\hline Pulse length & $4 \mathrm{~ns}$ \\
\hline Range & $60-1000 \mathrm{~m}$ \\
\hline Minimum measurement density & 4 points measurement $/ \mathrm{m}^{2}$ \\
\hline Altimetrical accuracy in open areas & $+/-0.15 \mathrm{~m}$ \\
\hline $\begin{array}{l}\text { Altimetrical accuracy in high } \\
\text { vegetation areas (vegetation }>70 \%)\end{array}$ & $+/-0.40 \mathrm{~m}$ \\
\hline Planimetric accuracy & $+/-0.30 \mathrm{~m}$ \\
\hline Measurement possibilities & Full waveform $(128 \mathrm{sample}$ rate $)$ \\
\hline
\end{tabular}




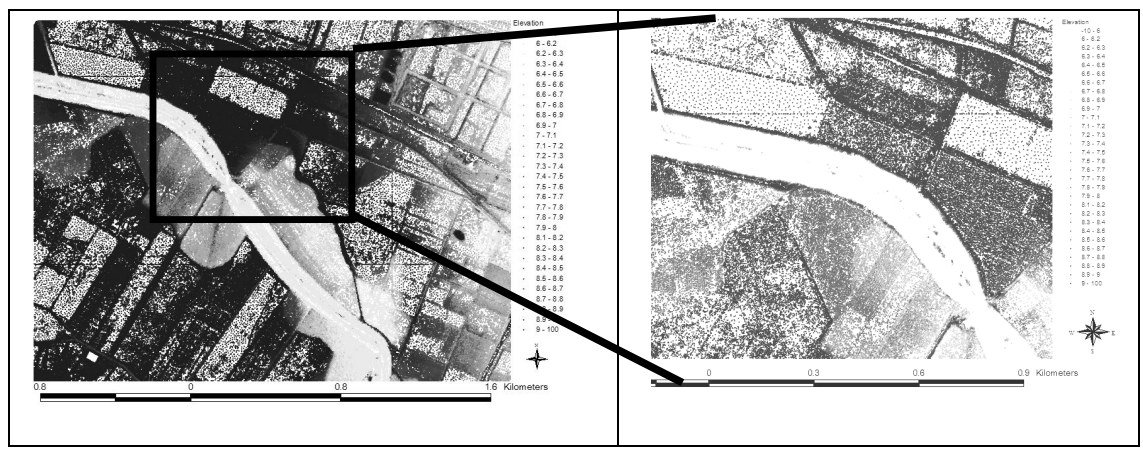

Figure 2: $\quad$ Sketch of MKP (Model Key Point) and a detail of key point's density distribution.

The elevation points of DSM (Digital Surface Model) obtained are classified into: default, ground, low vegetation, medium vegetation, high vegetation, buildings, low points and key points. The key points are the significant ground points: only these points compose the DTM, called Model Key Points (MKP), used during the hydraulic analysis. The MKP is light and manageable and doesn't use powerful software: in fact it shows many points in discontinuous areas but few points in homogeneous areas (fig. 2).

The laser scanning used is not able to determine the elevation point if clouds are present and under water level. As a consequence is not possible to use the laser scan data to carefully describe the riverbed. An evaluation of the differences in river bed elevation, obtained from the laser scan and from the GPS surveys on the ground, has been carried out, the surveyed river bed data have been integrated into the LiDAR in order to overcome the deficit of LiDAR data under water level.

\section{Model approach}

In general 1D and 2D numerical shallow water models are used in flood simulations. The solution of the complete 3D Reynolds equations are avoided because is computationally expensive. There are also hybrids models that combine, for example, 1D and 2D approaches. In this paper, hydrodynamic calculations were obtained using HEC-RAS with Geo-RAS extension (River Analysis System by USACE) $[12,13,14]$ for one-dimensional simulations and FLO-2D [1], MIKE 21 HD By DHI [15] and FLATModel [2] for twodimensional. HEC-RAS is a free software that estimates hydraulic profile of gradually varying motion in natural and artificial channel networks. FLO-2D is a commercial software. It has been listed twice on the Federal Emergency Management Agency (FEMA) list of approved hydraulic models and is a simple volume conservation model that distributes a flood hydrograph over a system of square grid element. MIKE 21 is a comprehensive modelling system for 2-D free surface flows, developed by Danish Hydraulic Institute (DHI). Many local 
research institutes, universities, and consulting firms have used the model extensively in simulation studies. The hydrodynamic module solves the equation of motion in the case of two dimensional plane, with the assumption of vertically homogeneous fluid under unsteady flow conditions. The implicit finite difference method of resolution is called ADI (Alternating Direction Implicit) method and the system of equations is solved with DS (Double Sweep, Abbott, 1979) method. The FLATModel [2] is a numerical hydrodynamic code that solves 2D shallow water equations using finite volume with Godunov's method [16], the integration is carried out on $\mathrm{z}$.

\section{Application and results}

The hydraulic simulations were carried out using a synthetic hydrograph [17] with a 30, 200 and 500 years return period flow, the peak values were evaluated with VAPI method [18], $\left(\mathrm{Q}_{\mathrm{T}=30}\right.$ is $1400 \mathrm{~m}^{3} / \mathrm{s}$ and $\mathrm{Q}_{\mathrm{T}=200}$ is $2270 \mathrm{~m}^{3} / \mathrm{s}, \mathrm{Q}_{\mathrm{T}=500}=$ $2700 \mathrm{~m}^{3} / \mathrm{s}$ ) as provided from Italian normative. The time base for each synthetic hydrograph is 170 hours. In the first phase of study the hydraulic resistance was evaluated using the Manning coefficient for the different type of land use. More accurate flow resistance studies will be done in the future to evaluate the resistance coefficients when the different echoes obtained from LiDAR data was used. As first approach the HEC-RAS model was used. A TIN (Triangulated Irregular Network) [19] of the floodplain area was created using the Model Key Point, and the stream area was improved using river topographical relief of 2003, (fig. 3). For each discharge, corresponding to different return period, the relative cross sections that contain the flow water was determined, in order to reach the correct representation of one dimensional hypothesis. The final computational geometry is the result of an iterative process. The hydraulic results, in terms of water level, top width and flow velocity, were exported in a GIS (Geographic Information System) using HEC-GeoRAS and represented on 2 meters

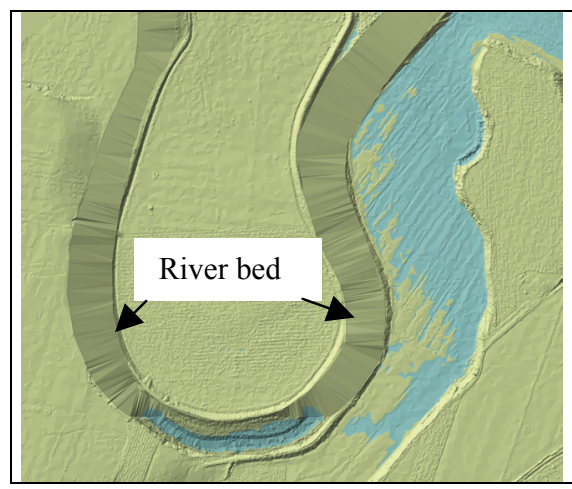

TIN built only with MKP, no reliable data under the sheet of water

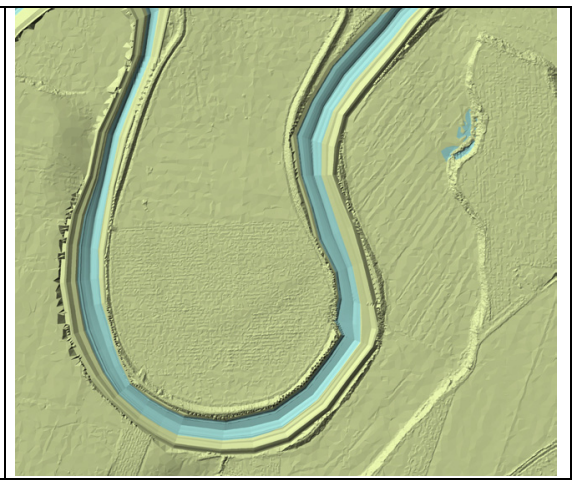

TIN built with MKP and topographic relief to put in evidence correctly the channel

Figure 3: $\quad$ TIN obtained from LIDAR data. 
resolution grid, in fig 4 for $\mathrm{TR}=200$ are reported the fifth and the sixth iteration. For each return period a specific computational geometry was created. This is one of the restriction of the one dimensional model, the setting up of the geometry, strongly influences the results. In a $2 \mathrm{D}$ model it is not necessary to define the computational cross sections, generally in very flat areas $2 \mathrm{D}$ models give better results; so FLO-2D, MIKE $21 \mathrm{HD}$ and FLATModel, were used to verify their performance.

The computational grid used by the software was obtained from Model Key Point. At first the results of bi-dimensional simulations were analyzed in terms of maximum flooded area. An index frequently used during model's validation has been considered $[20,21]$ :

$$
P=\frac{A_{\text {sim }} \cap A_{0 s s}}{A_{\text {sim }} \cup A_{0 s s}}
$$

in which $\mathrm{A}_{\text {sim }}$ is the simulated flood extension and $\mathrm{A}_{\text {oss }}$ is, instead, the observed one. In this study the evaluation of $P$ was realized using GIS tools, with the assumption that the observed flood extension is the same as simulated area with the higher grid resolution (5 meter), obtained with MIKE 21.

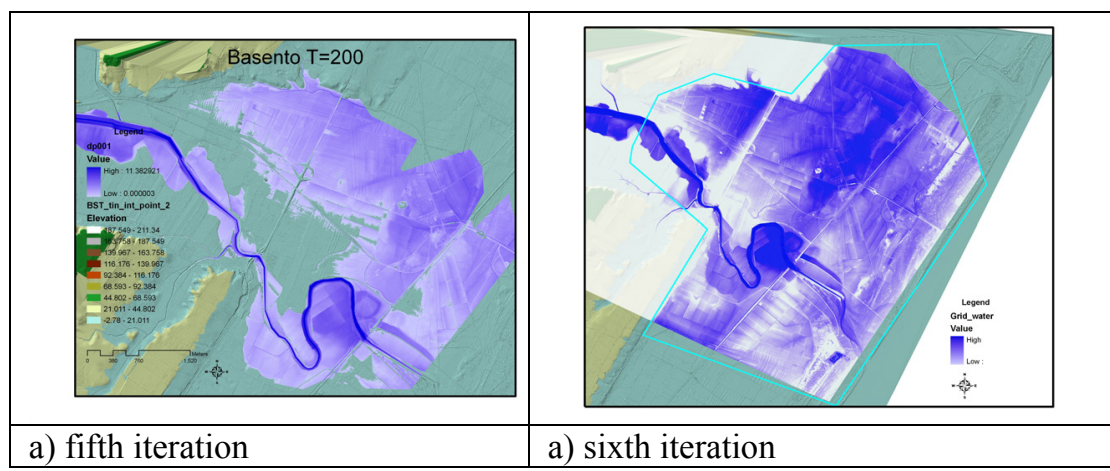

Figure 4: $\quad$ Maximum flooded area obtained by (HEC-RAS), for $\mathrm{Q}_{\mathrm{T}=200}=2270$ $\mathrm{m}^{3} / \mathrm{s}$.

The maximum cell resolution coupled with reasonable time consuming, for FLO-2D, has been $40 \mathrm{~m}$, for the FLATModel the grid size was $10 \mathrm{~m}$.

There are no significant differences in the inundated area for discharges with a given return period, in fact the index value is around $80 \%$ for each cell resolution value. For the one dimensional case, the $\mathrm{P}$ index assumes a lower value around $63 \%$. Different performances occur in the evaluation of hydraulic depth, $\mathrm{h}$. In particular, an analogous index $\mathrm{P}_{\mathrm{h}}$, eq. 3 , for $\mathrm{h}<30 \mathrm{~cm}$ (value of same order of magnitude of survey error) takes on a value near to $25 \%$ for each grid resolution $>10 \mathrm{~m}$, of simulated area. 


$$
P_{h}=\frac{A(h<30 \mathrm{~cm})_{\operatorname{sim}} \cap A(h<30 \mathrm{~cm})_{0 s s}}{A(h<30 \mathrm{~cm})_{\operatorname{sim}} \cup A(h<30 \mathrm{~cm})_{0 s s}}
$$

In figures 5 and 6 the results of maximum flooded areas are reported, Flo-2D and MIKE 21 use for $\mathrm{Q}_{\mathrm{T}=200}$ and FLATModel use $\mathrm{Q}_{\mathrm{T}=500}$. In fig 7 the flooded areas with $\mathrm{h}<30$. As expected, there are many differences between one-dimensional and two-dimensional models, in terms of extended areas and maximum hydraulic depth.

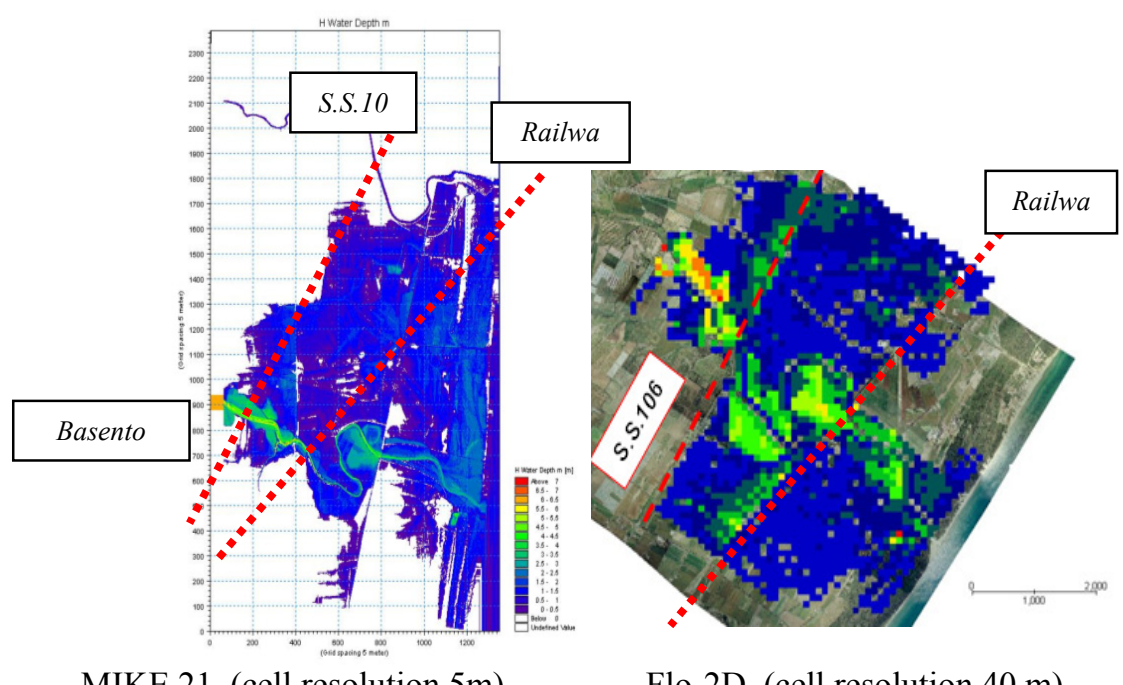

MIKE 21 (cell resolution 5m)

Flo-2D (cell resolution $40 \mathrm{~m}$ )

Figure 5: Hydrodynamic results of MIKE21 and FLO 2D for $T_{R}=200$ years.

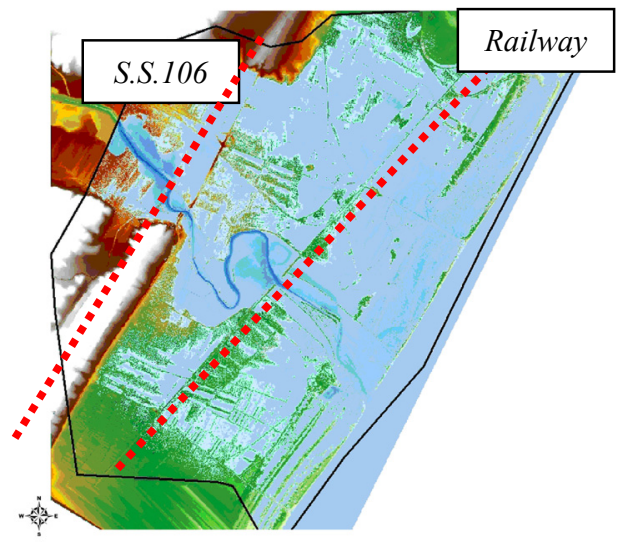

Figure 6: Hydrodynamic results of FLATModel for $T_{R}=500$ years. 


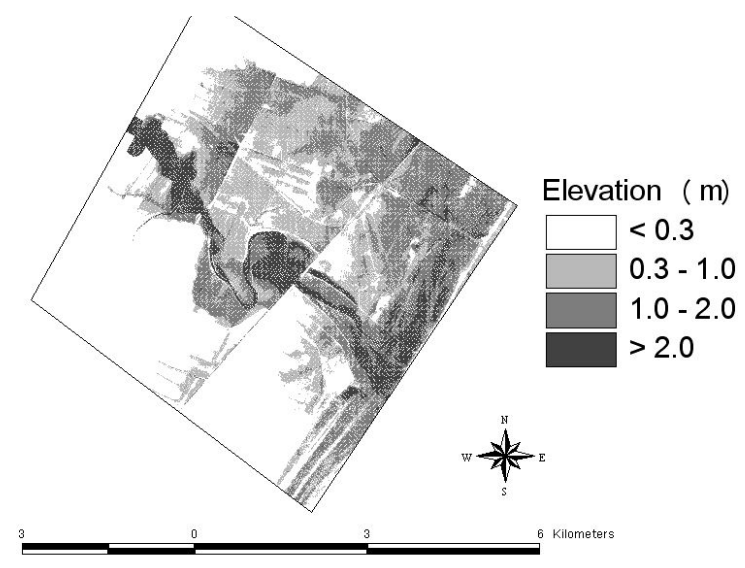

Figure 7: $\quad$ Flooded areas with depth values obtained from MIKE 21.

\section{Conclusion}

This paper shows the studies carried out to determine inundated areas along last branch of the Basento river, using high resolution input data (global position system GPS survey and high resolution laser altimetry data LIDAR) as input of one and two dimensional hydraulic models. The overall conclusion of this study is that accurate representation of topography allows accurate hydraulic simulation either with 1D or 2D models. Nevertheless in very flat areas, as those studied, two-dimensional models give better results in term of flooded areas due to the fact that this models give an accurate and continuous characterization of the terrain and man works that influence the flow dynamics and flood propagation (e.g. levees, embankments, roads, buildings), even if the 1D model cross sections are extrapolated from a high resolution data. Nevertheless, using 2D software, the flooded area seems to be independent of grid resolution as shown by the estimated $\mathrm{P}$ index. Likewise it does not occurs with the hydraulic depth, that does not appears correctly estimated with cell resolutions greater than $10 \mathrm{~m}$. Obviously, deeper examinations are necessary, other information derived from high resolution LiDAR data, will be taking into account such as flow resistance value (vegetation characteristics, water works and embankments) for each computational cell. In particular, water works and embankments, must be extracted from LiDAR data, and superimposed onto DTM as hard break lines in order to describe correctly the continuity of these structures.

\section{Acknowledgements}

The authors would also like to thank Basilicata Inter-Regional Basin Authority for the data availability and Andrea Cantisani for numerous models run and also the BTE-2002-0375, funds from Educational and Science Ministry of Spain. 


\section{References}

[1] O’Brien J., FLO-2D User Manual. Version 2007.06.

[2] V. Medina, M Hurlimannn, A. Bateman, Application of FLATModel, a 2D finite volume code, to debris flows in the northeastern part of Iberian Peninsula, Landslides, Springer Verlag Editor, 2007

[3] IMPACT Investigation of extreme flood Processes and Uncertainty. EVG1-CT2001-00037.

[4] CADAM European Concerted Action on Dam-break Modelling ENV4CT97-0555.

[5] FLOODsite: Integrated Flood Risk Analysis and Management methodologies. GOCE-CT-2004-505420

[6] Horritt, M. S. \& Bates, P.D. Effect of special resolution on a raster based model of flood flow. Hydrological Processes, 253, pp.239-249, 2001.

[7] Bates P. D., Marks K. J., Horritt M. S., Optimal use of high-resolution topographic data in flood inundation models. Hydrological Processes, 17, pp. 537-557, 2003.

[8] Frank E., Montoya M. \& Fattorelli S., Effect of topographic data resolution and spatial model resolution on a bi-dimensional hydromorphological model. River Basin Management IV, C.A. Brebbia \& K.L. Katsifarakis eds, WIT Press Southampton UK, pp. 325-334, 2007.

[9] Rosgen, D., Applied River Morphology, Wildland Hydrology, Pagosa Springs, Colorado, 1996.

[10] Casella V., Introduction to airborne laser scanning, a GPS-INS based technique Reports on Geodesy n. 3 (44), 1999, Warsaw University of Technology, pagg. 249-254, ISBN 83-85287-43-4 (1999).

[11] Casas A., Benito G., Thorndycraft V.R., Rico M., The topographic data source of digital terrain models as a key element in the accuracy of hydraulic flood modeling. Earth Surface Processes and Landforms 31, 444-456 (2006).

[12] HEC-RAS User Manual. Version 3.1 Hydrologic Engineering Center, United States Army Corps of Engineers, November (2002).

[13] Barkau R.L., "UNET One dimensional Unsteady Flow trough a full network of open channels user's manual”, US Army Corps of Engineering, Hydrologic Engineering Center, Davis, (1997).

[14] Dyhouse, G., Hatchett, J. \& Benn, J. Floodplain Modeling Using HECRAS (first edition), eds. Klotz D., Strafaci A., Hogan A., Dietrich K., Haestad Methods, (2005).

[15] DHI Software, MIKE 21 version 2004 - General Reference manual, Scientific Background, Danish Hydraulic Institute, 2004.

[16] LeVeque, R., Finite Volume Methods for Hyperbolic Problems. Cambridge University Press, 2002.

[17] Fiorentino M. e Margiotta M.R. La valutazione dei volumi di piena e il calcolo semplificato dell'effetto di laminazione dei grandi invasi, in "Tecniche per la difesa dall'inquinamento" ed. G. Frega, BIOS 203-222, 1998. 
[18] Claps, P. \& Fiorentino, M., Rapporto di sintesi sulla valutazione delle piene in Italia, Guida Operativa all'applicazione dei rapporti regionali sulla valutazione delle piene in Italia. Linea 1 Previsione e Prevenzione degli eventi idrologici estremi. CNR - GNDCI Roma, 1999.

[19] Sole A., Valanzano A., Digital terrain modelling, in Singh V. P. and Fiorentino M. eds., GIS in Hydrology, Water Science and Technology Library, Kluwer Academic Publishers, Dordrecht (NL), 1996.

[20] Horritt, M. S. \& Bates, P.D. Evaluation of $1 D$ and $2 D$ numerical models for predicting river flood inundation. Journal of Hydrology, 268, pp. 87992002.

[21] Di Baldassarre G., Castellarini A., Brath A., Horritt M., Bates, Modellistica idraulica monodimensionale: alcune considerazioni applicative sul grado di dettaglio ottimale della descrizione topografica. $\mathrm{XXX}^{\circ}$ Convegno di Idraulica e Costruzioni Idrauliche - IDRA 2006 